\title{
REFLECTIVE PRACTICE IN THE CONTEXT OF TEACHERS`CONTINUOUS PROFESSIONAL DEVELOPMENT
}

\author{
Ioana Stăncescu ${ }^{1}$, Luminița Mihaela Drăghicescu ${ }^{2}$, Ana-Maria Aurelia Petrescu ${ }^{3}$, \\ Gabriel Gorghiu ${ }^{4}$ \\ 1,2,3,4 Teachers Training Department, Valahia University of Targoviste, \\ ROMANIA \\ Email: ${ }^{1}$ stancescu_ioana@yahoo.com, \\ ${ }^{2}$ lumidraghicescu@yahoo.com, ${ }^{3}$ anapetrescu2007@yahoo.com, ${ }^{4}$ ggorghiu@ gmail.com
}

\begin{abstract}
Teachers continuous professional development is a priority at the level of the European Union. Good teachers mean good schools and quality education. In turn, good-quality education will be reflected in the sustainable competences of young people, in school success and professional success, in emphasizing the role of innovation and research in a society whose main capital is knowledge.

The dimension of quality in education has been strongly promoted over the last decade, both in educational policy and in current educational practices. One of the decisive aspects for ensuring the quality of the educational process is teacher training. The European Commission and the Council of the European Union have systematically highlighted the need to improve teachers training, to give importance to their continuous professional development, being aware of their major role in ensuring the effectiveness, efficiency and relevance of education systems.

In this context, the training of teachers as reflective practitioners must become a component of initial and continuous training programs for the teaching profession.

Being a reflective practitioner involves developing a set of specific values, attitudes and behaviors, including: respect for the child, education and teaching profession, responsibility and involvement in all stages of the teaching demarche, constant concern for regulation/self-regulation, optimizing their own behaviors, of the learning style of each student and of the learning outcomes, availability and competences for action-research, etc.

The present study focuses on highlighting the extent to which teachers value reflective practice and perceive it as one of the constituent elements of their teaching personality.
\end{abstract}

Keywords: continuous professional development, didactic personality, quality of education, reflective practice, reflective teacher

\section{INTRODUCTION}

Current educational policies and practices are constant related to a reference value concept: quality. Whether we are referring to the educational process carried out in the context of pre-university education, to tertiary education, to initial and continuous teacher training programs, to macro- or micro-level elements of the educational system, we design, analyze, evaluate, decide, apply measures to optimize/improve educational services, etc., from the perspective of the need of quality assurance. 
Yet, the early school leaving rate is at a worrying level, the rate of functional illiteracy, too, the teaching profession is an option for less and less graduates of higher education, and quality in education has become, rather, a slogan that we use only at the level of pedagogical discourse.

So, the following questions became so naturally: By whom depends decisively the quality of the education system? Who are the ones who implement the educational policy elements in such a way that they generate improvements in the school, in general, and in the teaching-learning-assessment process, in particular? Who are the ones who ensure that every child has equal chances to education?

All these interrogations are not just rhetorical, they are meant to focus attention on what the teacher really must represent. He is the one who has the power, has the force to change the "physiognomy" of the entire educational system. He is expected to promote successful educational practices, build / develop sustainable competences, build his didactic demarche, based on genuine values, share equitable his care, attention, love, so that each child to be sustained and stimulated to maximize his potential, to develop harmoniously in a school concerned with the state of well-being and the progress of each student. Synthesizing, from teacher and through teacher "comes" the quality.

However, in order to "translate" the quality into effective behaviors, into effective styles and didactic actions, able to produce the expected effects at the level of the school, the class and the individual student, the teacher must submit to the reflection, personal and / or in group, all the elements / the variables that influence the educational process and its outcomes. It is therefore necessary for reflectivity to become a feature of the teaching personality and reflective practice to complete the methodological repertory of any teacher, becoming an integral part of any educational/professional experience.

Reflection, as Griffiths write in a study titled The reflective dimension in teacher education (2000, p. 551), is aprioristic considered a valuable process that is likely to induce changes in teachers' educational practices.

Trying to demonstrate the decisive role of the reflection and relate it to the experience, Dewey (1992, p. 128) stated that it involves establishing the relationship between what we are doing and the consequences of our actions/ facts/ experiences. For an experience to be meaningful, it must be correlated with some degree of reflection.

Continuing to expose arguments in favor of reflection, Dewey appreciated that it demonstrates concern for the outcome (1992, pp. 130-131), while its lack demonstrates indifference. Extrapolating, a good teacher will always be concerned about the objective analysis of the results of his demarches, referring to the proposed objectives. So the reflection will be an intrinsic dimension of his teaching personality.

At the opposite pole, a teacher who perceives his profession as one like all others and summarizes it to teaching, seen as a transfer of knowledge to students, will never be a reflective teacher, ignoring the effects of his action on students. Self-sufficiency will characterize the didactic behavior of such a teacher, who considers himself the depositary of knowledge, and restricts his mission to sharing this knowledge, not counting in what way, what effects, what "traces" leaves this transfer to his "receivers".

In Dewey's view, reflexive experience has certain particularities that we can extend to reflective practice as a teacher's ability to undertake the analysis of his action before, during and after them. Synthesizing, these particularities lies in (1992, pp. 133-134):

- the dubitative character generated by the fact that the experience / action / situation is incomplete (is ongoing); 
- a contextual anticipation - the interpretation of the given elements is made according to the context, to the possible consequences of those, being determined by contextual factors;

- a holistic view of any consideration that may have an impact on the definition and clarification of the analyzed problem;

- elaboration of an experimental hypothesis necessary for the more precise delineation of the problem, correlated with a series of facts/actions;

- adopting a position on the formulated hypothesis materialized in an action plan compatible with contextual factors; application of the plan in order to produce the anticipated result, thus appreciating the validity of the proposed hypothesis.

Considering the transformative potential of reflection, the positive effects it can have on the educational act, we believe that it is necessary to integrate it, with the set of values, attitudes, didactic behaviors, abilities and tools subsumed, as a fundamental objective, both in the initial teacher training process as well as in the continuous professional development.

\section{PROBLEM STATEMENT}

In 2015 Joint Report of the Council and the Commission on the implementation of the strategic framework for European cooperation in education and training (ET 2020). New priorities for European cooperation in education and training is proposed, as a strategic objective, the improvement of the quality and efficiency of education and professional training. This objective contains, as priority domain, the firm support given to teachers, trainers, school managers and other staff from education. One of the specific aspects addressed in this priority area lies in supporting the promotion of excellence in teaching, at all levels, in the educational programs design and in the organization of learning and in stimulating structures and exploring new ways of measuring quality of pedagogical education (C 417, 2015).

Following this direction, obvious in all European Union member states, to invest in the continuous professional development of the teachers in order to improve the quality of teaching and, implicitly, the quality of the educational programs provided by the education system, we consider that the formation of a good practitioner in education is a continuous process in which any learning opportunity has to be capitalized, whether we refer to the school and professional contexts in which the teacher operates, or to the training system for the teaching career, with the two specific stages: initial and continuous training.

Being a good teacher today means to be aware, first of all, of the need for continuous training, for improvement, for development of the repertory of competences acquired during the initial training. In this context, reflective practice can become a central element. Furthermore, in the publication Teaching: The Reflective Profession (General Teaching Council for Northern Ireland, p. 12) is specified that reflective practice must be a constituent element of the professional identity of teachers and their teaching personality. This is not an additional skill, but a part of the teachers' thinking, being rather integrated holistically into all the competences of the teaching profession.

Such an approach calls for a series of interventions at the level of teacher training programs, which should also circumscribe a part of the practice of critical reflection. Analyzing how future teachers learn about the professional roles they will assume, N. Hoffmann (2016, p. 434) appreciates that learning about teaching is passive, consisting of the internalization of teaching methods presented in a "recipe" style, methods which, later, must be imitated within the lessons to be sustained. 
The improvement of teacher training practices involves, first of all, in the opinion of the same author, the change of the perception of teaching: it is a continuous process, likely to develop on the base of experience, on the accumulations generated by professional life. Thus, the one who carries out teaching activities, either as trainee or as a teacher, should reflect on their own actions, capitalizing in this way the reflective writings on his experiences, as well as the research projects focused on questioning his own practices (Hoffmann, 2016, p. 435). This creates the opportunity to learn from his own experiences, gaining a proper understanding of what teaching is about and, in general, of specific professional practices and roles.

In order to train teachers as reflective practitioners, it is necessary for the initial and continuous training process to ensure the internalization/development of a set of specific values, attitudes and behaviors that will be integrated in the profile of their teaching personality. Thus, the reflective teacher's personality will integrate the following values/qualities/attributes/characteristics/attitudes/behaviors:

- love, respect for the child;

- respect for education and its specific values;

- respect, devotion, attachment to the teaching profession;

- responsibility, professionalism;

- sustained motivation for continuous learning and professional development;

- pedagogical optimism;

- reflexive thinking;

- adequate sense of personal effectiveness;

- flexibility, willingness to change, including changing beliefs, educational practices, according to recent developments in psychology and educational sciences in particular;

- creativity, innovative spirit;

- critical and self-critical spirit;

- spirit of observation;

- team spirit, cooperation skills, group work;

- decisional capacity;

- increased resilience;

- conscious awareness of specific professional roles;

- valorization of collaborative learning, group work, including group reflection;

- valuing new technologies and integrating them into the educational process, including to support reflection;

- valorization of feedback;

- ability to receive and provide constructive feedback;

- willingness to share their own experiences and reflect on them in working / reflection groups;

- availability to use different methods / tools specific to reflective practices (reflection journals, feedback sheets, audio / video recordings, professional platforms, etc.);

- preoccupation for the progress / performance / success of each child;

- constant concern for improving the quality, efficiency and effectiveness of the educational act;

- comprehensive approach to teaching; 
- promotion of personal and group reflection;

- pedagogical valorization of mistakes / errors / failures, perceived as opportunities to learn etc.

Certainly, the inventory of the specific features of a reflective teacher is not complete, which is why our investigative approach also addressed this issue.

\section{RESEARCH QUESTIONS}

This study was conducted on the basis of the following research questions:

What reflective practice represent for teachers?

What are the main characteristics of a reflective teacher?

To what extent is reflective practice perceived as an integrated part of the teaching personality?

\section{PURPOSE OF THE STUDY}

The main purpose of the investigative study was to highlight the extent to which teachers develop a proper understanding of what reflective practice represents and perceive it as one of the constituent elements of their teaching personality.

Also, another purpose was to identify, based on respondent data, the main personality features / personality characteristics of a reflective teacher.

\section{RESEARCH METHODS}

In order to achieve the proposed goals, we used as research methods a questionnairebased survey and focus-group discussions. Information gathering which help us to answers to the research questions that guided the micro-research was done by administering a questionnaire, including both closed-response items and open-response items, and a semistructured discussion guide for focus-groups.

The sample of the research consists in 122 pre-university education teachers, working in various educational institutions in Dâmboviţa County, teachers for pre-school, primary, secondary and high-school education.

Recorded data were subjected to a quantitative analysis, correlated with a qualitative analysis, leading to the results presented in the following section of the study.

\section{FINDINGS}

The first of the items selected for our analysis was centered on identifying teachers' opinions on the meaning of reflective practice. Being an open item, the answers provided by the questioned teachers were numerous and varied. In order to better analyze and interpret data, we have organized these responses in four broad categories (some including subcategories), namely: defining reflective practice by reporting, in a holistic way, to didactic activity, defining reflective practice in relation to the main components / variables of didactic activity, defining reflective practice by reference to their own didactic style /their own behavior / their own educational practices / their own skills, qualities, defining reflective practice by reference to relations established by the teacher with students, parents and other teachers from school (Table no. 1).

Depending on the number of obtained answers, we have awarded ranks to each category and subcategories. 
Table no. 1. Definition of reflective practice in teachers`opinions

\begin{tabular}{|c|c|c|c|}
\hline No. & The criterion & $\begin{array}{l}\text { Defining reflective practice. } \\
\text { Examples of answers provided by teachers }\end{array}$ & Rank \\
\hline I. & didactic activity as a whole & $\begin{array}{l}\text { Interest in quality educational demarche; } \\
\text { Reflection on didactic activity for adopting measures } \\
\text { to improve it and ensure quality; } \\
\text { Reflection on didactic activity during its design, its } \\
\text { development and its completion; } \\
\text { Ascertainment of the progress in didactic activity. }\end{array}$ & $\mathrm{V}$ \\
\hline II. & $\begin{array}{l}\text { Main components / } \\
\text { variables of didactic } \\
\text { activity }\end{array}$ & - & \\
\hline 2.1. & didactic design & Improving didactic design. & VI \\
\hline 2.2 . & $\begin{array}{l}\text { realization of didactic } \\
\text { activity }\end{array}$ & - & \\
\hline 2.2.a. & $\begin{array}{l}\text { the objectives of the } \\
\text { didactic activity }\end{array}$ & $\begin{array}{l}\text { Establish educational objectives and analyze their } \\
\text { degree of achievement. }\end{array}$ & III \\
\hline 2.2.b. & $\begin{array}{l}\text { the teaching strategies } \\
\text { used }\end{array}$ & $\begin{array}{l}\text { Optimizing the teaching strategy; } \\
\text { Analysis of didactic strategies used; } \\
\text { Using the most appropriate methods and procedures } \\
\text { and educational instruments; } \\
\text { Optimizing the instructive-educational process by } \\
\text { choosing an optimal strategy; } \\
\text { Enrichment of didactic approaches with various } \\
\text { active-participatory strategies. }\end{array}$ & II \\
\hline 2.2.c. & contents & $\begin{array}{l}\text { Rigorous pedagogical processing of contents and their } \\
\text { adaptation to each class; } \\
\text { Establishing an optimal relationship between content } \\
\text { and learning experiences; }\end{array}$ & VII \\
\hline 2.2.d. & $\begin{array}{l}\text { educational / learning } \\
\text { environment }\end{array}$ & Ensure an adequate learning environment. & VIII \\
\hline 2.3 . & $\begin{array}{l}\text { the assessment activity, } \\
\text { focusing on students' } \\
\text { results }\end{array}$ & $\begin{array}{l}\text { Analyzing the results of students / preschoolers in } \\
\text { order to improve them; } \\
\text { Correct, objective evaluation of their own assessment } \\
\text { activity in order to increase its effectiveness; } \\
\text { Using modern assessment methods; } \\
\text { Optimizing the assessment act by using the most } \\
\text { appropriate assessment methods and tools. }\end{array}$ & II \\
\hline III. & $\begin{array}{l}\text { their own teaching style / } \\
\text { their own behavior / their } \\
\text { own educational practices / } \\
\text { their own competences and } \\
\text { qualities }\end{array}$ & $\begin{array}{l}\text { Perseverance; } \\
\text { Self-knowledge; } \\
\text { Analysis and optimization of their own didactic style; } \\
\text { Interest in continuous professional training / } \\
\text { professional development; } \\
\text { Rightness; } \\
\text { Professionalism; } \\
\text { New experiences, models, ideas; } \\
\text { Identifying the strengths and weaknesses of the } \\
\text { teaching style; } \\
\text { Documentation; } \\
\text { Using reflection journals; } \\
\text { Educational research. }\end{array}$ & $\mathrm{I}$ \\
\hline
\end{tabular}




\begin{tabular}{|c|c|c|c|}
\hline IV. & $\begin{array}{l}\text { relationships established } \\
\text { by the teacher }\end{array}$ & - & \\
\hline 4.1 . & with students & $\begin{array}{l}\text { Concern to meet the needs of children; } \\
\text { Very good knowledge of students - needs, interests, } \\
\text { resources; } \\
\text { Placing students in the center of the educational act, } \\
\text { their active involvement in learning; } \\
\text { Permanent concern for the psycho-emotional } \\
\text { development of the child; } \\
\text { Establishing a good relationship with students; } \\
\text { Identifying ways to differentiate and individualize; } \\
\text { Preoccupation for developing students' competences. }\end{array}$ & IV \\
\hline 4.2 . & with parents & $\begin{array}{l}\text { Improving the relationship between teacher and } \\
\text { parent. }\end{array}$ & IX \\
\hline 4.3 . & $\begin{array}{l}\text { with the other teachers in } \\
\text { the school }\end{array}$ & $\begin{array}{l}\text { Effectively communication with others; } \\
\text { Collaboration with other colleagues in the institution; } \\
\text { Share classroom experiences; } \\
\text { Involvement in educational projects. }\end{array}$ & VII \\
\hline
\end{tabular}

Analyzing centralized data in the table above, we note that:

- rank I (corresponding to the largest number of answers) was given to the definition of reflective practice in relation to their own didactic style / their own behavior / their own educational practices / their own competences, qualities, which leads us to the conclusion that reflection is associated, in the opinion of most of the questioned teachers, with their own didactic activity. This demonstrates the knowledge and understanding of the meaning of reflection as an intrinsic dimension of the educational process;

- rank II was associated with the responses provided by the teachers who defined the reflective practice by reference to one of the most important components of the lesson, the didactic strategy used. Reflection has as fundamental aim to optimize the educational process, and a variable with a major impact on it is the didactic strategy which the teacher chooses. The decision on the didactic strategy to be used is not an easy, but rather a complex approach, which must take into account and subject to reflection many elements of the educational process that are being approached in a systematic manner: the proposed objectives, the contents, the students - with all their particularities, interests, learning resources, etc.

- the rank II was awarded, also, on the basis of a number of answers equal to the one obtained in the category discussed above, to the definition of the reflective practice in relation to the assessment activity, with emphasis on the students' results. The results represent, for teachers, a relevant indicator for the quality of instruction, so it is normal for them to be subject of the reflection, with all that the evaluative act implies in its entirety;

- rank III was assigned to the definition of reflective practice in relation to the educational objectives, being aware that, together with the learning outcomes, these are the referential according to which the educational process is functioning.

On the basis of the answers obtained and further interpreted, we can conclude that the majority of teachers in our research sample understand the need for reflection as a vector for optimizing and improving the didactic activity.

However, we can't ignore the number of ten teachers in the research sample, who did not give any answer to this item, respectively did not define the reflective practice, which 
can lead us to the supposition that they have no information about this concept, which is explicable in the context in which the issue of this subject is rarely found in the educational offerings of the providers of training programs for the teaching profession.

The second item analyzed in the present study is also an open-response item through which teachers were asked to identify at least three characteristics of a reflective teacher. As in the previous item, in order to better analyze and disseminate the obtained data, we grouped the answers in several categories, representative of the teacher's main competences/personality traits (Table no. 2): characteristics that relate to the field of didactic training (didactic competences), characteristics related to the managerial activity of the teacher (managerial competences), characteristics integrated in the area of socio-emotional competences and characteristics that circumscribe personality traits (character, temperament, aptitude traits).

\begin{tabular}{|c|c|c|c|}
\hline No. & Category & Examples of answers provided by teachers & Rank \\
\hline 1. & $\begin{array}{l}\text { Didactic } \\
\text { competences }\end{array}$ & $\begin{array}{l}\text { well-trained, competent, able to choose optimal didactic } \\
\text { strategies, good knowledge of the content transferred to the } \\
\text { students, good designer of the activity, good evaluator, well } \\
\text { documented, professional / expert, able to adapt the contents to } \\
\text { the needs / competences of the students, good pedagogue, with } \\
\text { pedagogical tact, with professional dedication, capable of } \\
\text { retrospective analysis of didactic activity, concerned with the } \\
\text { improvement of the didactic behavior, concerned with the } \\
\text { analysis of its own teaching style, examiner of its own } \\
\text { educational practices, objective, efficient. }\end{array}$ & $\mathbf{I}$ \\
\hline 2. & $\begin{array}{l}\text { Managerial } \\
\text { competences }\end{array}$ & $\begin{array}{l}\text { good manager of the class of students, well-informed about the } \\
\text { group of students, organized, good communicator, able to } \\
\text { change their own behavior, to adapt their managerial style } \\
\text { according to the specifics of the students class, good observer, } \\
\text { competent in identifying problems and in their proper } \\
\text { management, operative, active. }\end{array}$ & III \\
\hline 3. & $\begin{array}{l}\text { Socio- } \\
\text { emotional } \\
\text { competences }\end{array}$ & $\begin{array}{l}\text { empathic, understanding, close to students, capable of self- } \\
\text { control, tolerant, sociable, good collaborator, cooperative, } \\
\text { available for dialogue / consultation with other teachers, able to } \\
\text { provide personalized support to students with learning } \\
\text { difficulties and gifted children, with love for children. }\end{array}$ & IV \\
\hline 4. & $\begin{array}{l}\text { Personality } \\
\text { traits } \\
\text { (character, } \\
\text { temperament, } \\
\text { aptitudes) }\end{array}$ & $\begin{array}{l}\text { serious, perfectionist, ambitious, capable of self-knowledge, } \\
\text { self-evaluation, persevering, consistent, eager to develop, } \\
\text { motivated for personal / professional development, open, } \\
\text { conscientious, adaptable, patiently, responsible, devoted, } \\
\text { demanding, attentive. }\end{array}$ & II \\
\hline
\end{tabular}

\section{Source: The authors of the article}

In order to achieve a good processing and interpretation of the collected data and finally to draw the portrait of the reflective teacher, we ranked the defined categories according to the number of answers given by the teachers (Table no. 2). Thus, rank I was attributed to the characteristics referring to the field of didactic activity, the rank II was associated with the characteristics related to the personality traits (character, temperament, aptitudes), the rank III - the characteristics included in the managerial activity and the rank IV - the integrated characteristics in the sphere of socio-emotional competences. Therefore, most respondents primarily relate to didactic competencies when asked to identify the characteristics of the reflective teacher, thus correlating the reflection with what constitutes the core / core element of a teacher's personality. 
By analyzing the examples of answers we provide for each set category, we can see their complexity and variety and the views of the teachers questioned about the characteristics that a reflective teacher should have.

We also note that some of the answers provided in this item do not apply only to what it means to be a reflective teacher, but generally to what a teacher should be.

On the one hand, this finding comes to confirm one of the above-mentioned ideas, that the reflective practice, implicitly the set of values, abilities, traits, attitudes, etc. it is not an additional skill, but a part of the teachers' thinking, merging with all the competences of the teaching profession.

On the other hand, we can assert that teachers have a lack of systematic, rigorous continuous professional training focused on the development of reflectivity on the didactic process, and they refer to the reflective act as they consider, so in a rather empirical manner.

The last item that we selected for analysis in this study focuses on teachers' opinions on the extent to which reflective practice is a component of their teaching personality.

Analyzing the answers provided by the teachers, as they are centralized in Figure no.1, we can see that quite a large percentage of teachers consider that reflective practice is a part of their teaching personality in a very good extend $(25 \%)$ and in a good extent $(62 \%)$. We can therefore see that most teachers think that reflective practice is a valuable dimension of their teaching personality.

From the distribution of responses, we note that no response is recorded on the lower stages of the Likert Scale. This may lead us to the idea that teachers want to avoid recognizing a reality that would damage their image, knowing, of course, the desirable answer, recognizing the benefits that reflection can bring to the teaching activity and the need for it to become an intrinsic dimension of personality teaching.

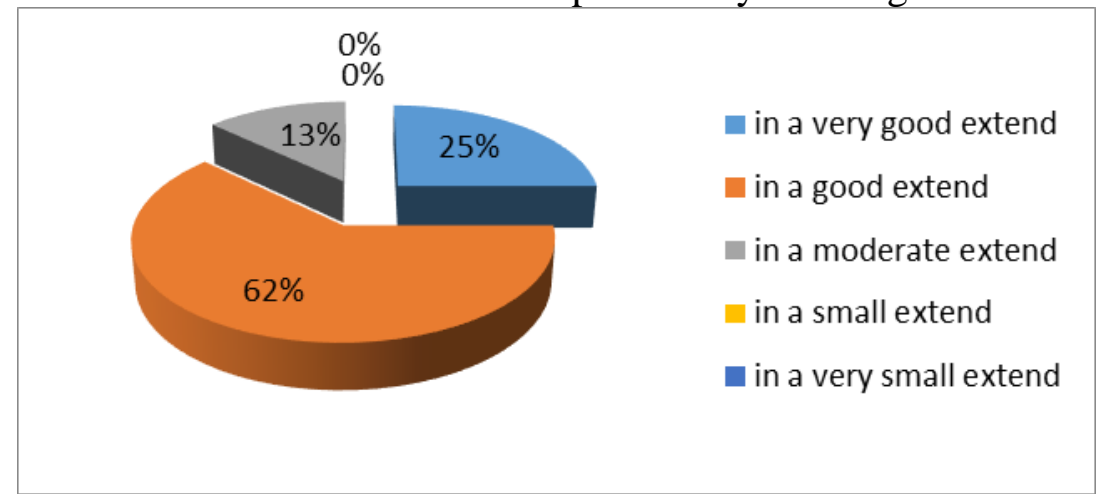

Figure no. 1. The extent to which reflective practice is a component of teachers`didactic personality

\section{CONCLUSION}

Source: The authors of the article

Reflective practice can have a major impact on the didactic process, on the direction of efficiency, optimization, and quality enhancement. However, we consider that reflective practice is not sufficiently well known and valued in current educational practices at this time. ideas:

The investigative approach made in this study allows us to infer the following synthetic

- teachers report reflective practice, primarily to their own didactic style and competences, and then on the main stages and components of the didactic process: design, realization (objectives, strategies, contents, learning environment), assessment. 
They also define reflective practice in relation to the didactic activity as a whole, but also to the relationships established by the teacher with the others (students, parents, colleagues);

- the teaching staff included in the study sample can identify a series of characteristics of the reflective teacher, especially mentioning characteristics that relate to the field of didactic training

- a significant percentage of teachers believe that reflective practice is an important part of their teaching personality.

The qualitative analysis of the data obtained from the administration of the questionnaire and the focus groups leads us to the conclusion that the teachers enrolled in the study have a fairly good image of the reflection on didactic activity but this is not sufficiently valued in educational practice, perhaps because it is not included as a distinct study discipline either in the initial training programs or in many of the continuous training programs, so many teachers do not know how to perform an effective reflective approach, what are the benefits and what tools they can use to facilitate reflection.

We therefore consider opportune to organize continuous training programs that directly target the teachers 'reflective practice and which will ensure the internalization of scientific notions, as well as some practical aspects regarding the integration of the reflection in the educational act, thus giving it more rigor and consistency.

We are convinced that profound changes in education, with sustainable effects, can only be the work of reflective teachers, teachers aware of the importance of their mission, responsible, willing to learn continually, to cooperate, to share experiences, to reflect on them, to change and change themselves - at the level of beliefs and pedagogical conception of teachers who, above all, respect the child, respect their profession and are animated by a superior motivation to constantly invest in their own professional development.

By preparing reflective teachers, we ensure the quality of the teaching process, aspiring to what is excellence in teaching and excellence in education, in general.

\section{BIBLIOGRAPHY:}

[1] Dewey, J. (1992). Fundamente pentru o știință a educației. București: Editura Didactică și Pedagogică R.A.

[2] Griffiths, V. (2000). The reflective dimension in teacher education. International Journal of Educational Research. 33 (2000) pp. 539 -555.

[3] Hoffmann, N. (2016). A învăța cum să predai. Colaborare, reflecție și cercetare în procesul de practică pedagogică. În Senge, P. (2016). Școli care învață: a cincea disciplină aplicată în educație. București: Editura Trei.

[4] General Teaching Council for Northern Ireland. Teaching: the Reflective Profession. Belfast: Albany House. Available from:

[5] https://www.gtcni.org.uk/uploads/docs/GTCNI_Comp_Bmrk\%20\%20Aug\%2007.pdf

[6] Jurnalul Oficial al Uniunii Europene. (15.12.2015). 2015 Joint Report for 2015 of the Council and the Commission on the implementation of the strategic framework for European cooperation in education and training (ET 2020). New priorities for European cooperation in education and training (2015/C 417/04). Available from:

[7] https://eur-lex.europa.eu/legal content/RO/TXT/PDF/?uri=CELEX:52015XG1215(02)\&from=EN

The contribution of the authors to this paper is equal. 